\title{
THE NEXUS AMONG EMPLOYMENT, PRODUCTIVITY AND TRADE OPENNESS: EVIDENCE FROM BRICS AND INDONESIA
}

\author{
Badri Narayan Rath* and Masagus M. Ridhwan** \\ * Corresponding author. Department of Liberal Arts, Indian Institute of Technology Hyderabad, India. \\ Email: badri@la.iith.ac.in \\ **Bank Indonesia Institute, Bank Indonesia, Jakarta, Indonesia.
}

\begin{abstract}
This paper investigates the nexus among employment, labor productivity and trade openness in Brazil, Russia, India, China, South Africa (BRICS), and Indonesia using annual data (1991-2018). The results suggest a long-run relationship among the variables but only in the agricultural sector of these economies. We also find a unidirectional causality running from employment to productivity in only the agricultural sector. Similarly, trade openness also Granger causes employment. Our final result indicates that trade openness positively influences labor productivity in the long-run. From a policy perspective, it is imperative for BRICS and Indonesia to target employment generation by promoting trade openness.
\end{abstract}

Keywords: Labor productivity; Trade openness; Sectoral change; Panel cointegration; BRICS; Indonesia.

JEL Classifications: C21; J21; O57.

Article history:

Received : March 26, 2020

Revised : July 15, 2020

Accepted : October 21, 2020

Available Online : December 31, 2020

https://doi.org/10.21098/bemp.v23i4.1363 


\section{INTRODUCTION}

One of the International Labor Organization's global employment agenda is to promote higher productivity and create employment opportunities for countries to improve standards of living and long-term sustainable growth (World Employment Report, 2004-05). Theoretically, labor productivity, employment and output are closely interlinked. This identity implies that, for any given economy, output growth can be achieved with either high productivity and low employment growth or with low productivity growth and high employment growth (Landmann, 2004).

Productivity is a measure of how effectively the economy's resources are translated into the production of goods and services. Over long periods of time, productivity is the single most important determinant of a nation's standard of living (Harris, 2002). On the other hand, employment plays a crucial role in the overall performance of a country. Thus, these two components are the most important indicators of economic growth of a country (Mills, 1952; Padalino and Vivarelli, 1997). According to the marginal productivity theory, high labor productivity leads to high real wages, which improves living standards. However, an increase in output per unit of labor requires more use of capital-intensive production techniques, which leads to mass destruction of employment. On the other hand, higher productivity leads to better technological progress, which improves the efficiency of the production process, allowing firms to produce more output with fewer workers. At the same time, productivity gains lead to employment creation as well, since technology also creates new products and new processes, which lead to the expansion of markets and additional job opportunities (Landmann, 2004; McMillan and Rodrik, 2011).

These two views on labor productivity growth seem contradictory. If higher labor productivity allows firms to get rid of workers, how can it raise the standard of living? Secondly, if technology creates new products, and higher demand for those products creates job opportunities, then, how unemployment rate increases in an economy? The third aspect of this study is trade openness, which has been linked to productivity and employment. The advocates of liberal trade regimes debate that one of the main recipients of greater trade openness are the country's workers.

In developing countries, given excess supply of labor, trade can encourage producers to relocate output in favour of labor-intensive goods. The resulting increase in the demand for labor leads to an increase in employment (Krugman and Lawrence, 1994; Edward, 1998). Trade openness is also the main channel of technology transfers and knowledge spillovers. Edwards (1998) shows a significant relationship between openness and productivity growth; however, an increase in trade openness reduces job destruction (Christev et al., 2008).

The aim of this paper is to undertake a detailed investigation on the nexus between employment, labor productivity and trade openness in selected emerging 
countries. ${ }^{1}$ The study emphasizes on BRICS and Indonesia because these big emerging countries have achieved remarkable growth and inflows of foreign investment, and have undergone a structural change and substantial reduction in poverty. These six emerging countries also have relatively large population sizes, along with similar features, including structural changes and offer interesting lessons for low income developing countries for their sectoral growth dynamics . Although the bulk of the existing literature focuses on the linkages between either employment and productivity (Bhattacharya and Narayan, 2010; Bhattacharya et al., 2011; McMillan and Rodrik, 2011; Junankar, 2013; Samargandi, 2018; Dinh Long et al., 2019; Moussri and Chatri, 2020), or trade and employment, or trade and productivity (Pieper, 1998; Wacziarg and Wallack, 2013; Greenway et al., 1999; Kucera et al., 2012; Dollar, 1992; Sachs and Warner, 1995; Edwards, 1998; Miller and Upadhyay, 2000; and Soderbom and Tea, 2003), there is hardly any study on the linkages among these three key macroeconomic indicators for these BRICS and Indonesia. Given that these countries have opened up their economies through economic reforms, particularly in 1980s and 1990s, examining the relationship between employment and labor productivity in the presence of trade openness at the sectoral level would further strengthen the debate on employment, trade and productivity nexus.

Against this backdrop, the paper aims to examine the relationships among employment, labor productivity and trade openness for BRICS countries and Indonesia. This paper differs from the earlier works in two novel ways. First, for emerging countries like BRICS and Indonesia, macroeconomic stabilization depends on both productivity and employment, which can adjust per capita income growth and overall inequality. However, little attention has been given to the dynamic adjustment of the economic structure of employment and labor productivity along with the significant trade openness adopted by many developing countries in 1990s and 2000s. Second, here economic structure is defined as the sectoral composition of employment and labor productivity and we examine the nexus between these two variables along with trade openness by considering the agricultural, industrial and service sectors. Industry or manufacturing has long been documented for its role as "leading sector" or "engine of growth" in the development process (Kaldor, 1966). Overall, this paper attempts to verify whether any long-run relationship exists among employment, labor productivity and trade openness for agricultural, manufacturing and service sectors of BRICS and Indonesia.

This study provides the following insights. The results show an existence of a long-run relationship among employment, labor productivity and trade openness

\footnotetext{
One of the important lessons from the current COVID-19 pandemic is that countries have become more open and, as a result, they have become more susceptible to external shocks like the COVID-19 outbreak; see Akram et al. (2020), Vidya, and Prabheesh (2020), Chen et al. (2020), Devpura (2020), Devpura and Narayan (2020), Iyke (2020a, b, c), Khattak et al. (2020), Liu, Sun and Zhang (2020), Liu, Choo and Lee (2020), Mishra et al. (2020), Narayan (2020a, b, c), Narayan, Devpura and Wang (2020), Narayan, Phan and Liu (2020), Narayan, Gong and Ahmed (2020), Phan and Narayan (2020), Sha and Sharma (2020), Sharma \& Sha (2020), and Sharma (2020) for studies exploring the impact of the COVID-19 pandemic on economies). Therefore, understanding how openness affects indicators like employment and productivity is of importance to economic agents.
} 
in the agricultural sector and an absence of any such relationship in the industrial and service sectors. The panel causality results also indicate a unidirectional causality running from employment to productivity in the agricultural sector. Similarly, trade openness also panel Granger causes employment, but the results derived from the long-run estimates indicate that trade openness positively affects labor productivity. Overall, the impact of labor productivity and trade openness on labor markets in BRICS and Indonesia is either minimal or insignificant.

The rest of the paper is in four sections. Section II briefly reviews the literature. Section III presents the theoretical framework, econometrics methodology and data. Section IV presents a preliminary analysis of the sectoral structure and empirical results. Section V draws the conclusions.

\section{REVIEW OF LITERATURE}

This section discusses why the nexus among employment, productivity and trade liberalization is considered as one of the contentious areas of macroeconomics. We begin by understanding the channels through which productivity may be improved by trade activities - Bloom et al. (2016) provide perhaps the most intuitive explanation. First, trade induces productivity improvements by shifting resources and output from less productive to more productive and efficient firms, and a new technological introduction may play a key role for this productivity and efficiency (see, for example, Melitz and Redding, 2013). This channel is the so-called reallocation effects channel. The second channel is through the impact of trade on innovation, which may arise due to competition (Porter, 1990). More competitive and innovative firms are more likely to survive and become winners in long run. The emergence of China as a global factory and a country that is also endowed with a large market size alongside rising innovation could dominant in world market. The declining trade barriers across countries including EU and US can help high-tech industries to grow relatively faster than low-tech industries, while in case of China the reduction in trade barriers made favorable for low-tech industries to grow further. However, as pointed out by Bloom et al. (2016), the aggregate changes following trade liberalization have occurred within rather than between industries, and hence there are strong reallocation effects, whereby lowtech firms tend to shrink and exit because of China.

Unlike trade and productivity, the impact of trade on employment is still not clear in the literature. A strand of literature suggests that globalisation and trade openness significantly reduce the equilibrium unemployment rate. This literature features studies such as Melitz (2003), Mitra and Ranjan (2010), and Gozgor (2014) for the case of developed countries. In similar vein, some studies conducted on emerging economies - e.g. Lo Turco and Maggioni (2013) for Turkey, Ridhwan et al., 2015; Simorangkir (2008), Widyasanti (2017), Vidya and Prabheesh (2019) for Indonesia, Joshi and Omkarnath (2020) for India, and Kucera et al. (2012) for India and South Africa-show a synchronized trade and employment between these countries and their trading partners (the European Union and the United States, in particular).

In contrast, another strand of literature casts a doubt on whether trade openness (liberalization) or such a movement from autarky to free trade could really create 
jobs (Feenstra, 1998; Ranjan, 2012). Simply speaking, globalisation may increase the long-run unemployment rate (see, for example, Egger and Kreickemeier, 2009; Helpman and Itskhoki, 2010, for developed countries). A recent study by Autor and Dorn (2013) finds a substantial impact of China in reducing US employment since the year 2000, particularly among low-skilled workers (see also, Bloom et al. (2016). In contrast, Greenway et al. (1999) found that the UK trade volumes with East Asian countries (both in terms of imports and exports) cause reductions in the level of derived labor demand in the UK. This finding is mainly in line with Feenstra and Hanson (1996), who pointed out that trade may also result in the relocation abroad of the most labor-intensive stages of the production process. An interesting study in India by Vashisht (2016) found that, despite the direct impact of trade on employment in the Indian manufacturing sector being positive, the indirect effect of trade on employment has been negative as an increase in export orientation as well as an increase in import penetration have reduced the derived demand for labor; therefore, the overall employment gains from trade tend to be minimal.

So far, the surveyed literature posits bilateral effects between trade openness and productivity as well as between trade and employment. This study, however, attempts to link all these variables together to enhance our knowledge and policy perspectives. The increasing export and import activities following trade liberalization may improve firm productivity due to a shift towards new technology, and in turn a reduction in firm employment. The positive effect of trade on firm employment could also happen via other channels. For example, in Turkey, imports and exports may positively and directly impact a firm's scale of production, thus pushing the firm's demand for labor upward. Also, the improvements in productivity stemming from trade externalities may foster firm competitiveness, which may indirectly lead to growth in firm output and market share. To sum up, despite the contrasting pieces of evidence on the effects of trade on employment and productivity, policy makers in developing countries inevitably, should be concerned about how to upgrade the competitiveness of their domestic firms to enable them penetrate global markets.

\section{THEORETICAL FRAMEWORK, METHODOLOGY AND DATA}

\section{A. Theoretical Framework}

The concept of labor productivity and employment is very much highlighted in Adam Smith's Wealth of Nations (Smith, 1776). According to Adam Smith, economic growth is nothing but the sum of labor productivity growth and employment growth. Labor productivity is the main factor in the determination of per head output, while employment growth depends on the structure of the production processes and the type of capital in use (Joshi and Omkarnath, 2020). Similarly, from a theoretical perceptive, the Heckscher-Ohlin model and Samuelson (1948) demonstrate the benefits of international trade and its implication on the labor market. Subsequently, Helpman and Itskhoki (2010) demonstrate the linkage between trade openness and the labor market. According to them, trade openness increases a country's rate of unemployment and reduces employment in the presence of market frictions. A theoretical linkage along with a methodological 
line for examining the impact of trade and labor productivity on employment in the literature is either through the growth accounting framework or through labor demand equation approach Greenway et al. (1999); Vashisht, 2016). In this paper, we follow the growth accounting framework ${ }^{2}$, as the baseline equation, which can be written as:

$$
\Delta E_{i t}=\Delta_{i 1}\left(1-S_{i 0}\right) \Delta D_{i}+\Delta X_{i t}+\Delta_{i 1}\left(S_{i o}-S_{i 1}\right) D_{i 1}+\Delta L P_{i} Q_{i 0}
$$

where $\Delta E$ denotes change in employment, $\Delta D$ denotes change domestic consumption, $\triangle X$ stands for exports, $L P=L / Q$ is the labor productivity, $Q$ denotes output, $S$ denotes the share of imports in total domestic consumption, $i$ represents $\mathrm{i}^{\text {th }}$ sector and $t$ refers to time.

\section{B. Methodology}

This section outlines the approach to investigating the nexus among employment, labor productivity and trade openness using panel unit root test, panel cointegration and causality tests. ${ }^{3}$ Further to examining the nexus among these three variables, the study make use of three models, each representing the agricultural, industrial and service sectors.

$$
\begin{aligned}
& E A_{i t}=\alpha_{0 i}+\beta_{1 i} L P A_{i t}+\beta_{2 i} T O_{i t}+e_{i, t} \\
& E I_{i t}=\theta_{0 i}+\delta_{1 i} L P I_{i t}+\delta_{2 i} T O_{i t}+u_{i, t} \\
& E S_{i t}=\varphi_{0 i}+\lambda_{1 i} L P S_{i t}+\lambda_{2 i} T O_{i t}+v_{i, t}
\end{aligned}
$$

where Equations (2), (3) and (4) are Models (I), (II) and (III), respectively; $E A_{i t}$ is employment in the agricultural sector, $E I_{i t}$ refers to employment in the industrial sector, $E S_{i t}$ is employment in the service sector, $L P A_{i t}$ refers to labor productivity in the agricultural sector, $L P I_{i t}$ is labor productivity in the industrial sector, $L P S_{i t}$ stands for labor productivity in the service sector, $T O_{i t}$ indicates trade openness, $\alpha, \theta$, and $\varphi$ are intercepts of the models. Similarly, $e, u$ and $v$ are the error terms, $i$ refers to number of countries and $t$ refers to time period starting from 1991 to 2018.

Before estimating these models, the study first examines the stationary properties of each of the seven variables using a first generation panel unit root test, Im, Pesaran, Shin (2003) test, which assumes no dependence of cross-sectional units as well as a second generation cross-sectional augmented (CIPS) panel unit root test developed by Pesaran (2007). If variables have a unit root at level, then, in the second step, we investigate their long-run relationship using the panel cointegration techniques developed by Pedroni (2004) and Westerlund (2007). The Pedroni (2004) test documents heterogeneity in the intercepts and is considered as a residual based method. Hence, to check the robustness of the test results, the

2 See Juhro et al. (2020) for an illustration of the growth accounting framework.

3 We thank the reviewer for suggesting that we apply time series tests for each country. However, since $\mathrm{T}$ (the number of years) is only 28 years, employing time series cointegration tests may not provide robust results. The study could also not include data prior to 1991, because of unavailability of sectorial employment data for BRICS and Indonesia. 
study employs the Westerlund (2007) test. The Westerlund (2007) test is extended to a heterogeneous panel framework and is based on a single equation errorcorrection models, and hence worth comparing with the Pedroni (2004) test. Third, we employ the panel DOLS estimator proposed by Kao and Chiang (2001) to obtain the long-run elasticity coefficients. The DOLS estimator is relatively better than fully-modified OLS (FMOLS) estimator, particularly in small panels when $N$ and $T$ up to 60 . Finally, in the fourth step, to assess the direction of causality, the study employs the Dumitrescu-Hurlin (2012) panel Granger causality test, which is robust to heterogeneity and cross-sectional dependencies in panels (see Dumitrescu and Hurlin, 2012).

\section{Data}

The study uses annual data for the period from 1991 to 2018 for six emerging countries (i.e. BRICS and Indonesia). The choice of beginning and end periods are purely based on availability of data for all six countries. The study uses data on employment, labor productivity, trade openness, gross value added and per capita gross domestic product (GDP). Further, we collect the employment and labor productivity data for the agricultural, industry and service sectors. Employment in each sector is measured as a percentage of total employment of the economy. The GDP and gross value-added data are in constant 2010 US\$. The gross value added in the agriculture, industry and service sectors are also measured as a shared of total GDP. Labor productivity in each sector is measured as a ratio of gross value added to employment. Trade openness is measured as exports plus imports as a percentage to GDP. All data are collected from the World Development Indicators (WDI) database published by the World Bank.

\section{EMPIRICAL RESULTS}

\section{A. Preliminary analysis}

Table 1 presents the shares of gross value added (GVA), employment and trade openness along with sectoral labor productivity in BRICS and Indonesia during 1991-2018. We begin by presenting the results for Brazil. The share of GVA in the agricultural sector has declined, on the one hand, from 1991 to 2018. However, the share of GVA in the service sector has increased, on the other hand, over the years. By looking at the employment share, the study notes that the service sector plays a dominant role in employment generation as compared to the industrial and agricultural sectors. Trade openness (exports plus imports as a percentage of GDP) has increased from $18.4 \%$ during $1991-2000$ to $25.5 \%$ during $2011-2018$. Despite this increase, it is indispensable to say that the trade openness of Brazil is lowest among the six countries. By looking at the labor productivity figures, we notice that the labor productivity in the industrial sector is higher than the labor productivity in the agricultural and service sectors. 
Table 1.

Share of Gross Value Added, Employment and Labor Productivity in BRICS and Indonesia

This table presents the average shares of gross value added, employment, and trade openness along with average sector-wise labor productivity in BRICS and Indonesia. The results based on gross value added indicate that the service sector is the dominant sector in BRICS and Indonesia. However, by looking at the employment share, it is clearly visible that the employment share of the service sector is significant in Brazil, Russia and South Africa; however, in Indonesia and India, the bulk of employment is generated by the agricultural sector. The sectoral average labor productivity figures show that labor productivity in the industrial sector is highest in all countries, except India, where labor productivity in the service sector is highest during 2000-2018. Note that GVAA = gross value added in the agricultural sector, GVAI = gross value added in the industrial sector, GVAS = gross value added in the service sector, $\mathrm{EA}=$ employment in the agricultural sector, $\mathrm{EI}=$ employment in the industrial sector, $\mathrm{ES}=$ employment in the service sector, $\mathrm{TO}=$ trade openness, $\mathrm{PGDP}=$ per capita gross domestic product, $\mathrm{LPA}=$ labor productivity in the agricultural sector, LPI = labor productivity in the industrial sector, LPS = labor productivity in the service sector.

\begin{tabular}{|c|c|c|c|c|c|c|c|c|c|c|c|}
\hline Year & GVAA & GVAI & GVAS & EA & EI & ES & TO & PGDP & LPA & LPI & LPS \\
\hline & \multicolumn{11}{|c|}{ Brazil } \\
\hline $1991-2000$ & 5.7 & 27.1 & 54.2 & 21.1 & 22.2 & 56.8 & 18.4 & 8396.1 & 27.0 & 122.3 & 95.3 \\
\hline $2001-2010$ & 4.9 & 23.2 & 57.1 & 18.8 & 21.6 & 59.6 & 26.3 & 9827.6 & 25.9 & 107.2 & 95.8 \\
\hline \multirow[t]{2}{*}{ 2011-2018 } & 4.4 & 20.1 & 61.1 & 11.0 & 21.8 & 67.2 & 25.5 & 11466.1 & 41.5 & 92.1 & 90.9 \\
\hline & \multicolumn{11}{|c|}{ China } \\
\hline $1991-2000$ & 18.9 & 45.5 & 35.7 & 53.1 & 23.9 & 23.0 & 33.6 & 1273.4 & 35.4 & 190.5 & 156.6 \\
\hline $2001-2010$ & 11.4 & 46.2 & 42.4 & 43.9 & 25.6 & 30.5 & 53.5 & 3043.8 & 26.0 & 180.6 & 140.4 \\
\hline \multirow[t]{2}{*}{ 2011-2018 } & 8.4 & 42.7 & 48.9 & 29.9 & 28.8 & 41.3 & 43.0 & 6315.3 & 28.1 & 148.3 & 118.5 \\
\hline & \multicolumn{11}{|c|}{ India } \\
\hline $1991-2000$ & 25.0 & 27.3 & 39.1 & 61.5 & 15.7 & 22.8 & 21.8 & 692.9 & 40.7 & 173.9 & 171.6 \\
\hline 2001-2010 & 18.0 & 29.5 & 44.7 & 55.3 & 19.4 & 25.4 & 40.6 & 1076.2 & 32.6 & 153.1 & 176.2 \\
\hline \multirow[t]{2}{*}{ 2011-2018 } & 16.3 & 27.9 & 47.4 & 46.0 & 24.3 & 29.7 & 47.6 & 1722.3 & 35.5 & 114.7 & 159.6 \\
\hline & \multicolumn{11}{|c|}{ Indonesia } \\
\hline $1991-2000$ & 17.8 & 42.2 & 39.2 & 46.9 & 17.0 & 36.1 & 60.7 & 2103.6 & 38.1 & 249.9 & 109.5 \\
\hline $2001-2010$ & 14.5 & 46.3 & 39.6 & 42.6 & 18.5 & 38.9 & 56.8 & 2610.4 & 34.2 & 250.5 & 101.9 \\
\hline \multirow{2}{*}{ 2011-2018 } & 13.3 & 41.3 & 42.4 & 33.6 & 21.4 & 45.0 & 44.8 & 3768.2 & 39.8 & 193.5 & 94.2 \\
\hline & \multicolumn{11}{|c|}{ Russia } \\
\hline $1991-2000$ & 7.1 & 37.6 & 47.7 & 14.6 & 33.7 & 51.7 & 60.0 & 6535.3 & 49.1 & 111.8 & 92.4 \\
\hline 2001-2010 & 4.5 & 30.7 & 51.7 & 9.8 & 29.2 & 61.0 & 55.2 & 9132.5 & 45.7 & 105.1 & 84.8 \\
\hline \multirow[t]{2}{*}{ 2011-2018 } & 3.4 & 29.6 & 55.3 & 6.7 & 27.3 & 65.9 & 47.9 & 11462.0 & 51.5 & 108.4 & 83.9 \\
\hline & \multicolumn{11}{|c|}{ South Africa } \\
\hline $1991-2000$ & 3.6 & 31.3 & 56.6 & 10.5 & 27.9 & 61.6 & 44.0 & 5711.7 & 34.8 & 112.2 & 91.8 \\
\hline $2001-2010$ & 2.8 & 27.8 & 59.9 & 7.6 & 27.4 & 65.0 & 57.8 & 6794.1 & 38.7 & 101.6 & 92.2 \\
\hline $2011-2018$ & 2.2 & 26.4 & 61.1 & 5.1 & 23.5 & 71.4 & 61.2 & 7505.6 & 43.5 & 112.2 & 85.6 \\
\hline
\end{tabular}

Second, we discuss the findings from China. The share of gross value added in the agricultural sector has declined over the years. The GVA share of the industrial sector, which dominated till 2010, has slightly declined (42.7\%) during 2011-2018. On the other hand, the GVA share of the service sector has increased consistently from 1991 to 2018. Similarly, the share of employment in the agricultural sector has declined, and the share of employment to total employment in both the industrial and service sectors has increased over the study period. Trade openness, which was on an average 54\% during 2001-2010, has declined to 43\% during 2011-2018. This clearly reveals that the export and import shares have decelerated, particularly 
from 2016 onwards. The labor productivity in the industrial sector is highest in comparison to agricultural and service sectors.

Third, we present the results obtained for India. The share of GVA in the agriculture sector has declined, while the GVA share of the service sector has increased like all the other countries. But it is worthwhile to mention that, despite the decline in the GVA share in India, it is still the highest (16.3\% during 20112018) among studied countries. The share of GVA in the industrial sector ranges between 27-29\% during 1991-2018. By looking at the employment figures, it is clearly evident that the agricultural sector plays a dominant role by absorbing the largest portion of India's labor force, although the share has declined over the years. It is also interesting to note that no other country is the largest proportion of employment still engaged in the agricultural sector as in India. Trade openness has also increased in India over the years. The productivity in the service sector is highest in comparison with the agricultural and industrial sectors.

Fourth, Indonesia being one of the leading emerging countries in the world, has also undergone a structural change. By looking at the GVA figures, the share of the agricultural sector has declined, which is not surprising, but it is worth mentioning that the GVA shares of both the industrial and service sectors equally contribute to the Indonesian economy. Similarly, employment shares in the agricultural sector has declined over the period from 1991 to 2018 . However, the shares of employment to total employment in the industrial and service sectors have increased over the years with the service sector representing the leading employment generator in recent years. Trade openness has also drastically declined in Indonesia from 1991 to 2018. The labor productivity of the industrial sector is higher than the labor productivity of the service and agricultural sectors.

Fifth, based on GVA and employment figures, Russia is clearly a service sector driven economy. The share of GVA of the agricultural sector is significantly low, while the GVA share of the industrial sector has also declined over the years. With regards to employment, the results also indicate that the employment share has declined in of the agriculture and industrial sectors, but the employment share in the service sector has increased. Like Indonesia, trade openness in Russia has also declined from $60 \%$ in 1991 to around $47 \%$ in 2018. The labor productivity of the industrial sector is highest, followed by the service and agricultural sectors, respectively. Finally, we also consider the economic structure of South Africa, which is appealing much like Russia, except that trade openness for South Africa has increased consistently over the years.

Next, Table 2 presents the annual average growth rates of sectorial composition. The figures for all indicators are based on annual average growth rates from 1991 to 2018. The first row of Table 2 indicates that the GVA share of the agricultural sector has declined in BRICS and Indonesia, with highest rate of decline recorded in China and Russia. The GVA share of the industrial sector's growth rates also reveals a decline in Brazil, Russia and South Africa, almost stagnant in China and Indonesia, and a marginal increase by $0.01 \%$ in India. The third row clearly shows an increasing growth rate of GVA in the service sector for all six countries, with Russia recording the highest growth and Indonesia recording the lowest growth. The negative growth of GVA in the agricultural sector truly reflects in the share of employment in the agricultural sector. The fourth row indicates that the growth 
rate of employment share to total employment has declined in all countries, with highest decline being recorded by Brazil (-3.0\%), followed by Russia (-2.9\%). Similarly, the growth rate of employment share in the industrial sector has been positive in three countries (India, Indonesia and China) and negative in the others (Russia, South Africa and Brazil). The growth rate of employment share in the service sector is positive for all six nations. with highest growth being reported in China, followed by Indonesia. The growth rate of labor productivity shows a diverse picture for all three sectors.

Table 2.

\section{Annual Average Growth Rates of Sectorial Composition in BRICS and Indonesia}

The figures for all indicators are based on annual average growth rates from 1991 to 2018. This table indicates that the GVA share of the agricultural sector has declined in BRICS and Indonesia, with highest rate of decline being recorded by China and Russia. The results suggest an increasing growth rate of GVA in the service sector for all six countries, with Russia being highest and Indonesia being the lowest. The negative growth of GVA in the agricultural sector is truly reflect in the share of employment in the agricultural sector. The growth rate of employment share in the service sector is positive for all six nations, with the highest growth being reported in China, followed by Indonesia. The growth rate of labor productivity shows a diverse picture for all three sectors. Notes GVAA = gross value added in the agricultural sector, GVAI = gross value added in the industrial sector, GVAS = gross value added in the service sector, $\mathrm{EA}=$ employment in the agricultural sector, $\mathrm{EI}=$ employment in the industrial sector, $\mathrm{ES}=$ employment in the service sector, LPA = labor productivity in the agricultural sector, LPI = labor productivity in the industrial sector, LPS = labor productivity in the service sector.

\begin{tabular}{lcccccc}
\hline & Brazil & China & India & Indonesia & Russia & South Africa \\
\hline GVAA & -0.8 & -4.3 & -2.2 & -1.4 & -4.3 & -2.0 \\
GVAI & -1.7 & 0.0 & 0.1 & 0.0 & -1.2 & -1.1 \\
GVAS & 1.1 & 1.6 & 1.0 & 0.5 & 1.7 & 0.6 \\
EA & -3.0 & -2.9 & -1.3 & -2.0 & -2.9 & -2.5 \\
EI & -0.3 & 1.1 & 1.8 & 1.7 & -1.4 & -0.7 \\
ES & 0.9 & 3.3 & 1.4 & 1.6 & 1.5 & 0.6 \\
LPA & 2.5 & -1.4 & -0.9 & 0.8 & -0.9 & 1.0 \\
LPI & -1.4 & -1.1 & -1.7 & -1.4 & 0.3 & -0.3 \\
LPS & 0.2 & -1.6 & -0.4 & -1.0 & 0.3 & 0.0 \\
\hline
\end{tabular}

Figure 1.

Trends of Labor Productivity in Agricultural Sector

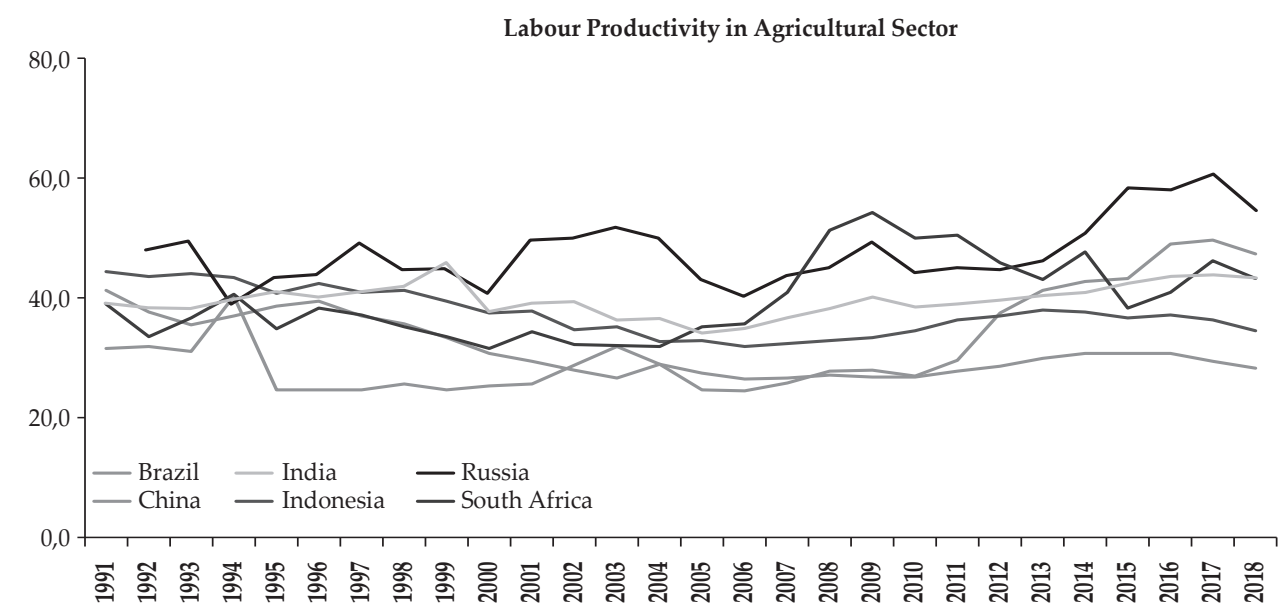


Figure 2.

Trends of Labor Productivity in Industrial Sector

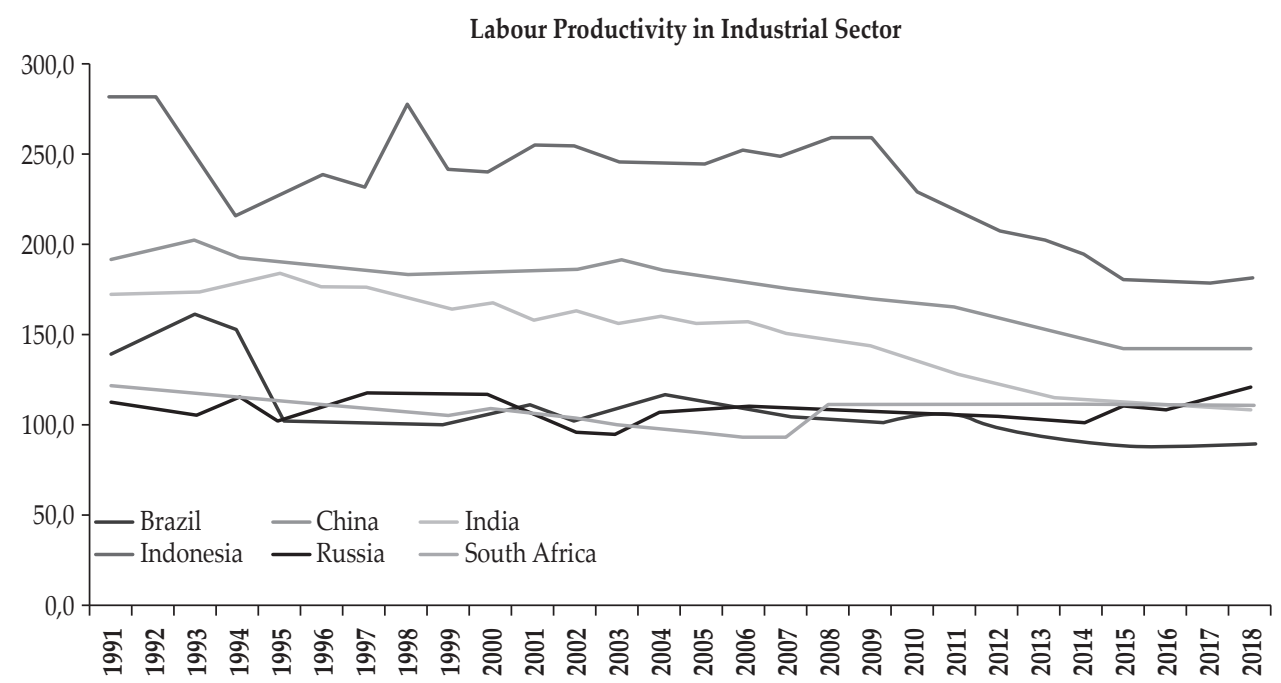

Figure 3.

Trends of Labor Productivity in Service Sector

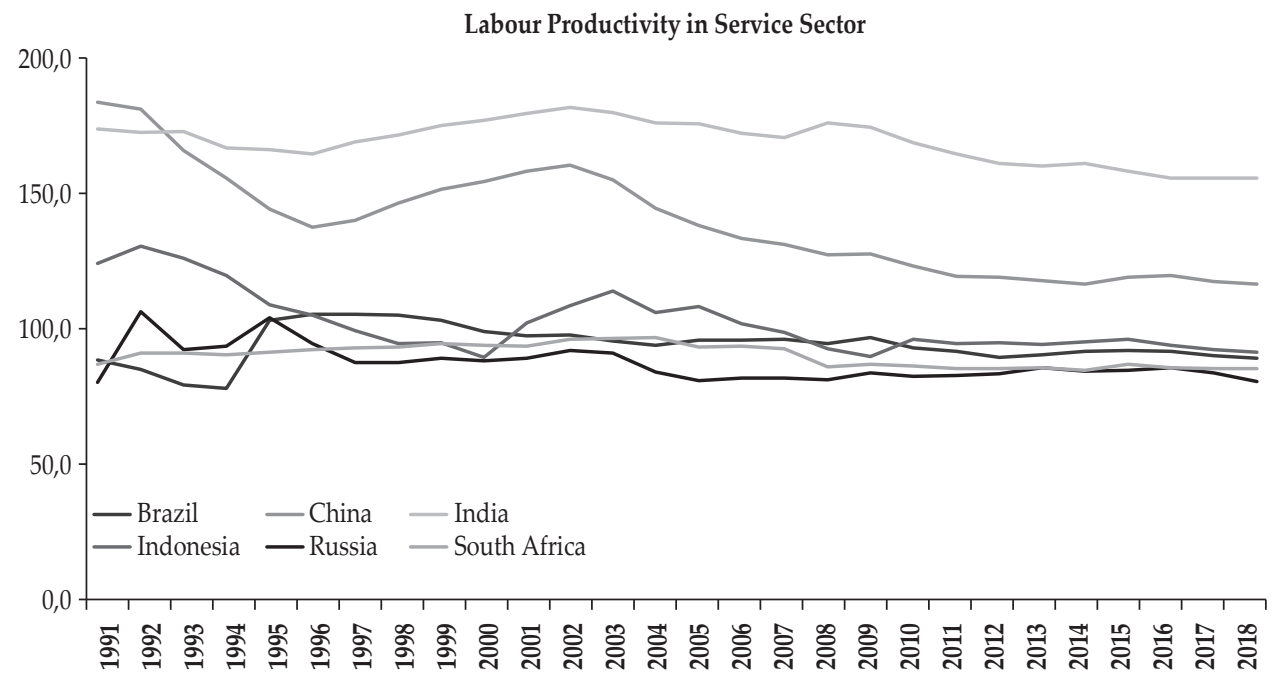

Figures 1 to 3 demonstrate the trends in labor productivity for the three sectors. First, Figure 1 clearly shows that the labor productivity oFigf the agricultural sector in Russia is the highest, followed by Brazil and South Africa. If we read Table 1, then, we notice that the shares of GVA and employment in the agricultural sector for these three countries are lower than those of China, India and Indonesia. Since the measurement of labor productivity is a ratio of GVA to per unit of labor, 
therefore, although in Russia and Brazil, less number of labor force is engaged in the agricltural sector, their contribution to output is much higher. Second, labor productivity in the industrial sector clearly indicates that Indonesia outshines other countries and is followed by China. Though India ranks third, its labor productivity shows a deceleration trend from 1991 to 2018. Third, the trends of labor productivity in the service sector clearly indicate that India outperforms the other countries, and this finding is not surprising because India is considered one of the global service giants; this finding is consistent with Rath (2018).

Figure 4 .

\section{Trend of Trade Openness in BRICS and Indonesia}

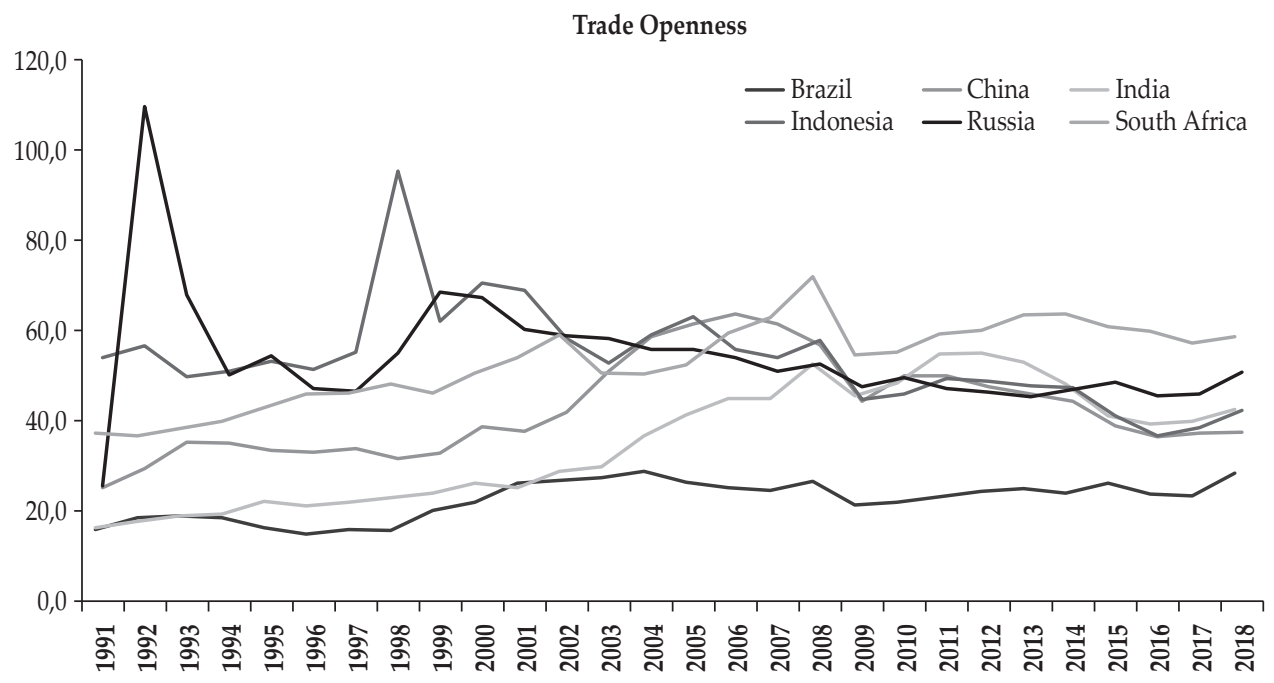

The Figure 4 shows the trends of trade openness in the six emerging countries. The figures reveal that both Russia and Indonesia were more open economies during 1991- 2000, but in the later years South Africa overtook both the countries. Similarly, China, which was showing a lower trade as a percentage of GDP in 1991, has significantly outperformed its counterparts after introducing many trade reforms. India, which was bottom among BRICS and Indonesia in 1991, has performed well by increasing its exports and imports volumes and values over the years. Brazil lags in trade openness among BRICS economies. 
Table 3.

\section{Panel Unit Root Test Results}

This table presents the panel unit root test results used to examine the stationarity properties of the seven variables. Unit root tests of Im, Pesaran, Shin (IPS) (2003) and Pesaran (CIPS) (2007) are reported by considering both the intercept and intercept and trend in the test regressions. The null hypothesis for IPS and CIPS is that the variables contain unit roots. The test results indicate that we accept the null hypothesis in the majority of cases and arrive at a conclusion that all seven variables are nonstationary at level and stationary at first difference. Note that ${ }^{* * *}$ and ${ }^{* *}$ represent $1 \%$ and $5 \%$ level of significance, respectively. The figures in parentheses indicate the probability values.

\begin{tabular}{lccccc}
\hline \multirow{2}{*}{ Variables } & \multicolumn{2}{c}{ IPS } & \multicolumn{3}{c}{ CIPS } \\
\cline { 2 - 6 } EA & C & C\&T & C & C\&T & lags \\
\hline \multirow{2}{*}{ EI } & 1.77 & 1.01 & -0.39 & -0.65 & 0 \\
& $(0.96)$ & $(0.84)$ & $(0.35)$ & $(0.25)$ & \\
ES & -1.04 & $-2.02^{* *}$ & -0.73 & 2.61 & 0 \\
& $(0.14)$ & $(0.02)$ & $(0.23)$ & $(0.99)$ & \\
LPA & 5.31 & 0.43 & 1.63 & 2.72 & 0 \\
& $(1.00)$ & $(0.66)$ & $(0.94)$ & $(0.99)$ & \\
LPI & $-3.70^{* * *}$ & -0.73 & -0.17 & -0.16 & \multirow{2}{*}{1} \\
\multirow{2}{*}{ LPS } & $(0.00)$ & $(0.23)$ & $(0.43)$ & $(0.43)$ & \\
\multirow{2}{*}{ TO } & 0.52 & -0.32 & -1.20 & -0.06 & 0 \\
& $(0.69)$ & $(0.37)$ & $(0.11)$ & $(0.47)$ & \\
& 0.46 & $-3.75^{* * *}$ & $-1.99^{* *}$ & -0.56 & 0 \\
& $(0.67)$ & $(0.00)$ & $(0.02)$ & $(0.28)$ & \\
& $-2.68^{* * *}$ & -0.15 & -0.64 & -0.23 & 2 \\
\hline
\end{tabular}

The panel unit root test results are reported in Table 3. These results are based on the IPS (Im et al., 2003) and CIPS (Pesaran, 2007) panel unit root tests under the null hypothesis that the variables contain unit roots. The results indicate that we accept the null hypothesis in the majority of cases and arrive at a conclusion that all seven variables are nonstationary at level and stationary at first difference.

Table 4.

\section{Pedroni Panel Cointegration Test Results}

This table presents the panel cointegration test results, which are based on the Pedroni (2004) test. Here, we controlled for both constant and trend (i.e. C\&T) in the regressions. These results clearly show that only in Model I can we reject the null hypothesis of no cointegration. This implies that there exist a long-run cointegration relationship among employment, labor productivity and trade openness in the agricultural sector. Note that ${ }^{* * *}$, ${ }^{* *}$, and ${ }^{*}$ represent $1 \%, 5 \%$ and $10 \%$ level of significance, respectively. The figures in parentheses indicate the probability values.

\begin{tabular}{lccccccc}
\hline Models & $\begin{array}{c}\text { Panel } \\
\text { v-Statistic }\end{array}$ & $\begin{array}{c}\text { Panel } \\
\text { rho- } \\
\text { Statistic }\end{array}$ & $\begin{array}{c}\text { Panel PP- } \\
\text { Statistic }\end{array}$ & $\begin{array}{c}\text { Panel } \\
\text { ADH- } \\
\text { Statistic }\end{array}$ & $\begin{array}{c}\text { Group } \\
\text { rho- } \\
\text { Statistic }\end{array}$ & $\begin{array}{c}\text { Group } \\
\text { PP- } \\
\text { Statistic }\end{array}$ & $\begin{array}{c}\text { Group } \\
\text { ADH- } \\
\text { Statistic }\end{array}$ \\
\hline C\&T & & & & & & & \\
\multirow{2}{*}{ Model I } & $10.89^{* * *}$ & -0.13 & $-1.76^{* *}$ & $-2.26^{* * *}$ & 0.67 & $-1.50^{*}$ & $-2.69^{* * *}$ \\
& $(0.00)$ & $(0.44)$ & $(0.03)$ & $(0.01)$ & $(0.74)$ & $(0.6)$ & $(0.00)$ \\
\multirow{2}{*}{ Model II } & -0.17 & 1.58 & 0.24 & $-1.46^{*}$ & 1.78 & 0.11 & -2.62 \\
& $(0.56)$ & $(0.94)$ & $(0.59)$ & $(0.07)$ & $(0.96)$ & $(0.54)$ & $(0.00)$ \\
\multirow{3}{*}{ Model III } & $3.32^{* * *}$ & 1.42 & 0.72 & 0.84 & 2.09 & 2.09 & 2.09 \\
& $(0.00)$ & $(0.92)$ & $(0.76)$ & $(0.79)$ & $(0.98)$ & $(0.89)$ & $(0.82)$ \\
\hline
\end{tabular}


Since we find the variables to be non-stationary at level, we can now check whether there is any evidence of a long-run relationship among employment, labor productivity and trade openness using the residual based cointegration test developed by Pedroni (2004). The results show that only in Model I can we reject the null hypothesis of no cointegration. This implies that there exist a longrun cointegration relationship among employment, labor productivity and trade openness in the agricultural sector. However, there is no cointegrating relationship among these three variables in the industrial and service sectors in BRICS and Indonesia.

Table 5.

Long-run Elasticities

This table indicates that labor productivity of the agricultural sector negatively affects employment, whereas trade openness positively affects employment in the agricultural sector. Note that ${ }^{* * *}$, and ${ }^{*}$ represent $1 \%$, and $10 \%$ level of significance, respectively. The figures in parentheses indicate the probability values.

\begin{tabular}{lccccc}
\hline & \multicolumn{2}{c}{ DOLS } & & FMOLS & TO \\
C\&T & LPA & TO & LPA & $0.03^{*}$ \\
\hline \multirow{2}{*}{ Model I } & $-0.19^{* * *}$ & 0.03 & $-0.21^{* * *}$ & $(0.09)$ \\
& $(0.00)$ & $(0.13)$ & $(0.00)$ & --- \\
Model II & --- & --- & --- & -- \\
Model III & --- & --- & -- & \\
\hline
\end{tabular}

Typically, after establishing the long-run relationship among variables, one would be interested in the long-run impact of explanatory variables on the dependent variable. We so in this study by estimating long-run elasticities using the DOLS and FMOLS estimators and report these results in Table 5. The study only presents the results obtained from the agricultural sector, as there was no evidence of a long-run relationship among the variables in the industrial and service sectors. The findings from Table 5 are as follows. First, a 1\% increase in labor productivity in the agricultural sector leads to an average decline in employment in this sector by approximately $0.2 \%$. The finding is consistent with theory that higher labor productivity leads to the substitution of capital-intensive production techniques for labor-intensive production techniques, which could potentially lead to mass destruction of jobs. The gain in productivity in the agricultural sector can lead to a reduction in employment as technological progress improves the efficiency of the production process, which is clearly visible in Table 2 . Second, the long-run elasticity of employment in the agricultural sector with respect to a change in trade openness $(0.03 \%)$ is positive. 
Table 6.

\section{Cross-sectional Dependence (CD) Test Results}

This table presents the CD test results. These results show evidence of cross-sectional dependence in the model. Note that ${ }^{* * *}$ and ${ }^{* *}$ represent $1 \%$ and $5 \%$ level of significance, respectively. The figures in parentheses indicate the probability values.

\begin{tabular}{|c|c|c|c|}
\hline Variables & CD Test & Correlation & Absolute Correlation \\
\hline$E A$ & $\begin{array}{c}18.78^{* * *} \\
(0.00)\end{array}$ & 0.92 & 0.92 \\
\hline$E I$ & $\begin{array}{c}-2.26^{* *} \\
(0.02)\end{array}$ & -0.110 & 0.59 \\
\hline ES & $\begin{array}{c}18.88^{* * *} \\
(0.00)\end{array}$ & 0.91 & 0.91 \\
\hline$L P A$ & $\begin{array}{l}4.14^{* * *} \\
(0.00)\end{array}$ & 0.20 & 0.29 \\
\hline$L P I$ & $\begin{array}{c}5.94^{* * *} \\
(0.00)\end{array}$ & 0.29 & 0.37 \\
\hline LPS & $\begin{array}{c}7.28^{* * * *} \\
(0.00)\end{array}$ & 0.35 & 0.42 \\
\hline TO & $\begin{array}{l}3.77^{* *} \\
(0.00)\end{array}$ & 0.18 & 0.41 \\
\hline
\end{tabular}

The panel cointegration test results based on the Pedroni (2004) test are only reliable in the absence of cross-sectional dependence (CD). Hence, we test for CD by using the Pesaran (2015) CD test. ${ }^{4}$ Table 6 presents these CD test results, and reveals the presence of cross-sectional dependence in the model.

Table 7.

Panel Cointegration Test Results Based on the Westerlund (2007) Test

This table shows the panel cointegration test results based on the Westerlund (2007) test, which takes into account cross-sectional dependence in the models. We test the null of no cointegration and the alternative hypothesis of cointegration. ${ }^{* * *}$ and ${ }^{* *}$ denote statistical significance at $1 \%$ and $5 \%$, respectively. The figures in the parentheses indicate the probability values. Gt, Ga, Pt, and Pa are the four-panel cointegration statistics developed by Westerlund (2007). Gt and Ga are the groups mean tests. Pt and Pa are the panel tests.

\begin{tabular}{lcccc}
\hline $\begin{array}{l}\text { Models } \\
\text { C\&T }\end{array}$ & Gt & Ga & Pt & Pa \\
\hline \multirow{2}{*}{ Model I } & $-3.10^{* *}$ & -3.49 & $-7.54^{* *}$ & -3.50 \\
& $(0.05)$ & $(1.00)$ & $(0.02)$ & $(0.99)$ \\
\multirow{2}{*}{ Model II } & -2.48 & -7.44 & $-8.74^{* * *}$ & -8.37 \\
& $(0.55)$ & $(0.98)$ & $(0.00)$ & $(0.78)$ \\
Model III & -1.24 & -1.55 & -4.24 & -5.83 \\
& $(1.00)$ & $(1.00)$ & $(0.94)$ & $(0.95)$ \\
\hline
\end{tabular}

4 The CD test is particularly important because in the presence of CD, the residual based cointegration tests will be inefficient (see Westerlund, 2007). 
Table 8.

\section{Dumitrescu-Hurlin (D-H) Causality Test Results for Model I at First Difference}

This table presents the Dumitrescu-Hurlin (2012) (D-H) panel causality test results. The D-H causality test is more effective in the presence of CD (see Dumitrescu and Hurlin, 2012). The results indicate that there is a unidirectional causality running from employment to labor productivity, from employment to trade openness, and from trade openness to labor productivity in the agricultural sector. Note that ${ }^{* * *}$ represents $1 \%$ level of significance. All variables are in first differences.

\begin{tabular}{lccc}
\hline Models & W-Stat. & Zbar-Stat. & $P$-values \\
\hline$L P A \rightarrow E A$ & 1.89 & -0.32 & 0.74 \\
$E A \rightarrow L P A$ & $4.77^{* * *}$ & $2.51^{* * *}$ & 0.01 \\
$T O \rightarrow E A$ & 1.72 & -0.49 & 0.62 \\
$E A \rightarrow T O$ & $5.19^{* * *}$ & $2.93^{* * *}$ & 0.00 \\
$T O \rightarrow L P A$ & $4.93^{* * *}$ & $2.67^{* * *}$ & 0.01 \\
$L P A \rightarrow T O$ & 1.48 & -0.72 & 0.46 \\
\hline
\end{tabular}

After identifying the presence of cross-sectional dependence in data, we check the robustness of our cointegration test results by employing the Westerlund (2007) panel cointegration test. The test results are reported in Table 7. The results in Table 7 do not corroborate those presented in Table 4. That is, there is no evidence of a long-run relationship among employment, labor productivity and trade openness in the agricultural sector, as two out of four statistics are significant. Similar findings are also noticed in the manufacturing and service sector results. Finally, this study executes the D-H panel causality test. D-H test produces more consistent results in the presence of cross-section dependence and heterogeneity in the data (see Dumitrescu and Hurlin, 2012). The results based on the D-H causality test, which are reported in Table 8, show the evidence of a unidirectional causality running from employment to labor productivity, but not the other way round. Similarly, the results reveal that employment causes trade openness but not the reverse. Further, the pair-wise causality between trade openness and labor productivity shows a unidirectional causality running from in trade openness to labor productivity in the agricultural sector. To summarize, based on our empirical results, we find little or no evidence on the nexus among employment, labor productivity and trade openness in BRICS and Indonesia. Our findings, to some extent, match earlier studies such as Liu and Trefler (2008), Gorg and Gorlish (2012), Geishecker and Gorg (2013), which also found minimal or no effect of trade openness on the labor market.

\section{CONCLUSIONS}

This paper examined the nexus among employment, labor productivity and trade openness in BRICS and Indonesia. Although there are reasonable number of studies, which empirically examined the relationship between employment and productivity, productivity and trade, and labor demand function, none examined the linkage among these three variables. To investigate this linkage, we picked BRICS and Indonesia because these six emerging countries have undergone several economic and trade reforms, which resulted in structural changes in their 
economies. The study made use of annual data on trade openness, employment, and labor productivity of three key sectors (primary, secondary and tertiary) of these economies from 1991 to 2018. The results indicate that the economic structures of these countries have changed over the last three decades and employment and productivity alongside trade openness have played a significant role in these structural changes. Further, this study employed panel cointegration and causality tests to assess the long-and short-run relationships among trade openness, employment and productivity. The results derived from the panel cointegration tests revealed an existence of a long-run relationship in only the agricultural sector. The panel causality results also indicate a unidirectional causality running from employment to labor productivity growth in only the agricultural sector. Similarly, trade openness Granger causes employment; but based on the DOLS method, trade openness positively affects labor productivity in the long run. To sum up, we find little or no evidence on the nexus among employment, labor productivity and trade openness in BRICS and Indonesia.

From a policy perspective, it is imperative for BRICS and Indonesia to target employment generation by promoting trade openness. Although an increase in labor productivity adversely affects employment in the agricultural sector, boosting labor productivity in the service sector should be the key goal of policy makers, since all these countries are already moving towards service-driven economies. India is of course the exception, where labor productivity in the service sector is relatively high in comparison to Indonesia and other BRICS nations, but the service sector needs to absorb employment from the agricultural sector, where the bulk of the labor force is still in disguised unemployment.

\section{REFERENCES}

Akram, V., Rath, B. N., \& Sahoo, P. K. (2020). Do COVID-19 Cases Follow a Similar Transition Path? Evidence from Indian states. MethodsX, 101196. https://doi. org/10.1016/j.mex.2020.101196

Autor, D.H., \& Dorn, D. (2013). The Growth of Low-skill Service Jobs and the Polarization of the US Labor Market. American Economic Review, 103, 15531597.

Bhattacharya, M., \& Narayan, P.K. (2010). Labor Productivity Trends in Australian Manufacturing: Some Time Series Properties. Applied Economics, 42, 3221- 3230.

Bhattacharya, M., Narayan, P.K., Popp, S., \& Rath, B.N. (2011). The ProductivityWage and Productivity-Employment Nexus: A Panel Data Analysis of Indian Manufacturing. Empirical Economics, 40, 285-303.

Bloom, N., Draca, M., \& Van Reenen, J. (2016). Trade Induced Technical Change? The Impact of Chinese Imports on Innovation, IT and Productivity. The Review of Economic Studies, 83, 87-117.

Chen, C., Liu, L., \& Zhao, N. (2020). Fear Sentiment, Uncertainty, and Bitcoin Price Dynamics: The Case of COVID-19. Emerging Markets Finance and Trade, 56, 2298-2309. https://doi.org/10.1080/1540496X.2020.1787150

Christev, A., Kupets, O., \& Lehmann, H. (2008). Trade Liberalization and Employment Effects in Ukraine. Comparative Economics Studies, 50, 318-340. 
Devpura, N. (2020). Can Oil Prices Predict Japanese Yen? Asian Economics Letters, 1. https://doi.org/10.46557/001c.17964

Devpura, N., \& Narayan, P.K. (2020) Hourly Oil Price Volatility: The Role of COVID-19. Energy Research Letters, 1, 13683. https://doi.org/10.46557/001c.13683

Dinh Long, P., Ngoc, P. T.B., \& Görg, H. (2019). Trade Liberalization and Labor Market Adjustments: Does Rent Sharing Matter? Emerging Markets Finance and Trade. DOI: 10.1080/1540496X.2019.1643316.

Dollar, D. (1992). Outward-oriented Developing Economies Really Do Grow More Rapidly: Evidence from 95 LCDs, 1976-1985. Economic Development and Cultural Change, 40, 523-544.

Dumitrescu, I.E., \& Hurlin., C. (2012). Testing for Granger Non-Causality in Heterogeneous Panels. Economic Modelling, 29, 1450-1460.

Edwards, S. (1998). Openness, Productivity and Growth: What Do We Really Know? Economic Journal, 108, 383-398.

Egger, H., \& Kreickemeier, U. (2009). Firm Heterogeneity and the Labor Market Effects of Trade Liberalization. International Economic Review, 50, 187-216.

Feenstra, R., \& Hanson, G.H. (1996). Foreign Investment Outsourcing and Relative Wages. American Economic Review, 86, 252-257.

Feenstra, R.C. (1998). Integration and Disintegration in the Global Economy. Journal of Economic Perspectives, 12, 31-50.

Geishecker, I., \& Gorg, H. (2013). Services Offshoring and Wages: Evidence from Micro Data. Oxford Economic Papers, 65, 124-146.

Gorg, H., \& Gorlish, D. (2012). Trade and Labor Market Outcomes in Germany, in 'Policy Priorities for International Trade and Jobs', by D. Lippoldt (Eds), Chapter 6, pp. 193-236, OECD Publishing.

Gozgor, G. (2014). The Impact of Trade Openness on The Unemployment Rate in G7 Countries. The Journal of International Trade and Economic Development, 23, 1018-1037.

Greenway, D., Hine, R.C., \& Wright, P. (1999). An Empirical Assessment of The Impact of Trade on Employment in The United Kingdom. European Journal of Political Economy, 15, 485-500.

Harris, R. (2002). Determinants of Productivity Growth: Issues and Prospects. In Productivity Issues in Canada, ed. S. Rao and A. Sharpe. Calgary: University of Calgary Press.

Helpman, E., \& Itskhoki, O. (2010). Labor Market Rigidities, Trade and Unemployment. Oxford Journals. The Review of Economic Studies, 77, 1100 1137.

Im, K., S., Pesaran M., H., \& Shin, Y. (2003). Testing for Unit Roots in Heterogeneous Panels. Journal of Econometrics, 115, 53-74.

Iyke, B. (2020a) COVID-19: The Reaction of US Oil and Gas Producers to the Pandemic. Energy Research Letters, 1, 13912. https://doi.org/10.46557/001c.13912

Iyke, B. N. (2020b). Economic Policy Uncertainty in Times of COVID-19 Pandemic. Asian Economics Letters, 1. https://doi.org/10.46557/001c.17665

Iyke, B.N. (2020c). The Disease Outbreak Channel of Exchange Rate Return Predictability: Evidence from COVID-19. Emerging Markets Finance and Trade, 56, 2277-2297. https://doi.org/10.1080/1540496X.2020.1784718 
Joshi, D.P.P., \& Omkarnath, G. (2020). Trade, Productivity and Employment Nexus: An Examination in Post-reforms India. Journal of Developing Areas, 54, 1-18.

Juhro, S. M., Narayan, P. K., Iyke, B. N., \& Trisnanto, B. (2020). Is There a Role for Islamic Finance and R\&D in Endogenous Growth Models in the Case of Indonesia? Pacific-Basin Finance Journal, 101297. https://doi.org/10.1016/j. pacfin.2020.101297

Junankar, P.N. (2013). Is there a Trade-off between Employment and Productivity? IZA Discussion Papers, 7717, Institute of Labor Economics (IZA).

Kaldor, N. (1996). Causes of Growth and Stagnation in the World Economy. Cambridge: Cambridge University Press.

Kao, C., \& Chiang, M. (2001). The Estimation and Inference of a Cointegrated Regression in Panel Data, In: Baltagi, B.H., Fomby, T.B. and Carter Hill, R. (Ed.) Nonstationary Panels, Panel Cointegration, and Dynamic Panels (Advances in Econometrics, 15, 179-222), Emerald Group Publishing Limited, Bingley.

Khattak, M. A., Ali, M., \& Rizvi, S. A. R. (2020). Predicting the European Stock Market during COVID-19: A Machine Learning approach. MethodsX, 101198. https://doi.org/10.1016/j.mex.2020.101198

Krugman, P.R., \& Lawrence, R.Z. (1994). Trade, Jobs and Wages. Scientific American, 207, 44-49.

Kucera, D., Roncolato, L., \& Von Uexkull, E. (2012). Trade Contraction and Employment in India and South Africa during the Global Crisis. World Development, 40, 1122-1134.

Landmann, O. (2004). Employment, Productivity and Output Growth. (Employment Strategy Papers, 2004/17). International Labor Oranization. https://www.ilo. org/wcmsp5/groups/public/---ed_emp/---emp_elm/documents/publication/ wcms_114299.pdf

Liu, D., Sun, W., \& Zhang, X. (2020) Is the Chinese Economy Well Positioned to Fight the COVID-19 Pandemic? The Financial Cycle Perspective. Emerging Markets Finance and Trade, 56, 2259-2276. https://doi.org/10.1080/154049 6X.2020.1787152

Liu, M., Choo, W-C., \& Lee, C-C. (2020) The Response of the Stock Market to the Announcement of Global Pandemic. Emerging Markets Finance and Trade, 56, 3562-3577. https://doi.org/10.1080/1540496X.2020.1850441

Liu, R. \& Trefler, D. (2008). Much Ado About Nothing: American Jobs and the Rise of Service Outsourcing to China and India (NBER Working Paper No. 14061). National Bureau of Economic Research.

Lo Turco, A. \& Maggioni, D. (2013). Does Trade Foster Employment Growth in Emerging Markets? Evidence from Turkey. World Development, 52, 1-18.

McMillan, M. S., \& D. Rodrik. (2011). Globalization, Structural Change and Productivity Growth (NBER Working Paper No. 17143). National Bureau of Economic Research.

Melitz, M. (2003). The Impact of Trade on Intra-industry Reallocations and Aggregate Productivity Growth. Econometrica, 71, 1695-1725.

Melitz, M., \& Redding, S. (2013). Firm Heterogeneity and Aggregate Welfare (Centre for Economic Performance Discussion Paper, 1200). Centre for Economic Performance. 
Miller, S.M., \& M, Upadhyay. (2000). The Effect of Openness, Trade Orientation, and Human Capital on Total Factor Productivity. Journal of Development Economics, 63, 399-423.

Mills, F.C. (1952). The Role of Productivity in Economic Growth. American Economic Review, 42. 545-557.

Mishra, A.K., Rath, B.N., \& Dash, A.K. (2020) Does the Indian Financial Market Nosedive Because of The COVID-19 Outbreak, in Comparison to After Demonetisation and the GST? Emerging Markets Finance and Trade, 56, 21622180. https://doi.org/10/1080/1540496X.2020.1785425.

Mitra, D., \& Ranjan, P. (2010). Offshoring and Unemployment: The Role of Search Frictions Labor Mobility. Journal of International Economics, 81, 219-229.

Moussir, C. \& Chatri, A. (2020). Structural Change and Labor Productivity Growth in Morocco. Structural Change and Economic Dynamics, 53, 353-358.

Narayan, P. K. (2020a). Oil Price News and COVID-19-Is There Any Connection? Energy Research Letters, 1, 13176. https://doi.org/10.46557/001c.13176

Narayan, P. K. (2020b). Has COVID-19 Changed Exchange Rate Resistance to Shocks? Asian Economics Letters, 1. https://doi.org/10.46557/001c.17389

Narayan, P. K. (2020c). Did Bubble Activity Intensify During COVID-19? Asian Economics Letters, 1. https://doi.org/10.46557/001c.17654

Narayan, P.K., Devpura, N., \& Wang, H. (2020). Japanese Currency and Stock Market-What Happened during the COVID-19 Pandemic? Economic Analysis and Policy, 68, 191-198.

Narayan, P.K., Gong, Q., \& Ahmed, H.J.A. (2020) Is there a Pattern in how COVID-19 has affected Australia's Stock Returns? Applied Economics Letters, https://doi.org/10.1080/13504851.2020.1861190 .

Narayan, P.K., Phan, D.H.B., \& Liu, G. (2020) COVID-19 Lockdowns, Stimulus Packages, Travel Bans, and Stock Returns. Finance Research Letters. https://doi. org/10.1016/j.frl.2020.101732

Padalino, S., \& Vivarelli, M. (1997). The Employment Intensity of Economic Growth in G-7 Countries. International Labor Review. Summer 136, 2.

Pedroni, P. (2004). Panel Cointegration: Asymptotic and Finite Sample Properties of Pooled Time Series Test with An Application on the PPP hypothesis. Econometric Theory, 20, 597-625.

Pesaran, M., H. (2007). A Simple Panel Unit Root Test in the Presence of Cross Section Dependence. Journal of Applied Econometrics, 22, 265-312.

Pesaran, M., H. (2015). Testing Weak Cross-Sectional Dependence in Large Panels. Econometric Reviews, 34, 1089-1117.

Pesaran, M.H. (2004). General Diagnostic Tests for Cross Section Dependence in Panels (CESifo Working Paper Series 1229). CESifo.

Phan, D.H.B., \& Narayan, P.K. (2020). Country Responses and the Reaction of the Stock Market to COVID-19-a Preliminary Exposition. Emerging Markets Finance and Trade, 56, 2138-2150. https://doi.org/10.1080/1540496X.2020.1784719

Pieper, U. (1998). Openness and Structural Dynamics of Productivity and Employment in Developing Countries: A Case of De-industrialization? ILO Employment and Training Working Papers No. 14.

Porter, M. (1990). The Competitive Advantage of Nations. Macmillan, London. 
Ranjan, P. (2012). Trade Liberalization, Unemployment, and Inequality with Endogenous Job Destruction. International Review of Economics and Finance, 23, 16-29.

Rath, B.N., (2018). Productivity Growth and Efficiency Change: Comparing Manufacturing- and Service-based Firms in India. Economic Modelling, 70, 447457.

Ridhwan,M.M., Wicaksono, G., Nurliana, L., Bary,P., Suryani, FT., \& Satyanugroho, R. (2015). Analysis of Competitiveness and National Strategic Industries in the Era of the ASEAN Economic Community and Free Trade (Bank Indonesia Working Papers No. 3). Bank Indonesia.

Sachs, J. \& Warner, A. (1995). Economic Reforms and the Process of Global Integration. Brooking Papers on Economic Activity, 1,1-118.

Samargandi, N. (2018). Determinants of Labor Productivity in MENA Countries. Emerging Markets Finance and Trade, 54, 1063-1081.

Samuelson, P.A. (1948). International Trade and the Equalisation of Factor Prices. The Economic Journal, 58, 163-184.

Sha, Y., \& Sharma, S.S. (2020) Research on Pandemics. Special Issue of the Journal Emerging Markets Finance and Trade, 56, 2133-2137. https://doi.org/10.1080/154 0496X.2020.1795467

Sharma, S.S., \& Sha, Y. (2020) Part A: Special Section on COVID-19 Research. Emerging Markets Finance and Trade, 56, 3551-3553. https://doi.org/10.1080/154 0496X.2020.1858617

Sharma, S. S. (2020). A Note on the Asian Market Volatility During the COVID-19 Pandemic. Asian Economics Letters, 1. https://doi.org/10.46557/001c.17661

Simorangkir, I. (2008). The Openness and Its Impact to Indonesia Economy: A Structural VAR Approach. Bulletin of Monetary Economics and Banking, 10, 1-38.

Smith, A. (1776). An Inquiry into the Nature and Causes of the Wealth of Nations. Volume I, W. Strahan and T. Cadell, London.

Soderbom, M. \& Teal, F. (2003). Openness and Human Capital as Source of Productivity Growth: An Empirical Investigation. Centre for Study of African Economics, Working Paper Series/2003-06, 1-30.

Vashisht, P. (2016). Creating Manufacturing Jobs in India: Has Openness to Trade Really Helped? Journal of Asian Economics, 42, 53-64.

Vidya, C.T. \& Prabheesh, K.P. (2019). Intra-Industry Trade Between India and Indonesia. Bulletin of Monetary Economics and Banking, 21, 511-530.

Vidya, C.T., \& Prabheesh, K.P. (2020). Implications of COVID-19 Pandemic on the Global Trade Networks. Emerging Markets Finance and Trade, 56, 2408-2421. https://doi.org/10.1080/1540496X.2020.1785426

Wacziarg, R. \& Wallack, J.S. (2004). Trade Liberalization and Intersectoral Labor Movements, Journal of International Economics, 64, 411-439.

Westerlund, J. (2007). Testing for Error Correction in Panel Data. Oxford Bulletin of Economics and Statistics, 69, 709-748.

Widyasanti, A.A. (2017). The Impact of New Trade Agenda to Macroeconomic Performance of Indonesia and Japan in Short and Long Term. Bulletin of Monetary Economics and Banking, 20, 1-22.

World Employment Report. (2005). 2004-05: Employment, Productivity and Poverty Reduction. International Labor Organization. 
This page is intentionally left blank 